\title{
Glycerin as a factor for moderating quality changes in table eggs during storage
}

\author{
Kamil Drabik $^{1}$, Patrycja Chabroszewska ${ }^{1}$, Kostiantyn Vasiukov ${ }^{1}$, Agnieszka Adamczuk $^{2}$, and \\ Justyna Batkowska ${ }^{1}$ \\ ${ }^{1}$ Institute of Biological Basis of Animal Production, University of Life Sciences in Lublin, 13 Akademicka St., \\ 20-950 Lublin, Poland \\ ${ }^{2}$ Central Laboratory of Agroecology in Lublin, 3B Dobrzański St., 20-262 Lublin, Poland \\ Correspondence: Justyna Batkowska (justyna.batkowska@up.lublin.pl)
}

Received: 15 March 2018 - Revised: 8 June 2018 - Accepted: 30 June 2018 - Published: 18 July 2018

\begin{abstract}
Glycerol, a by-product of biodiesel production, is non-toxic to humans and the environment. With the current increase in the demand for fuels obtained from biomass, the amount of glycerine waste production is increasing. There are many ways to dispose this substance (in pharmaceuticals, cosmetics, and in chemical industry), but its utilization is still insufficient. Therefore, the aim of this study was to assess the possibility of limiting quality changes in table eggs during storage by coating the shells with a glycerol solution. The material used in this research consisted of 270 table chicken eggs collected on the same day. On the first day of the experiment, quality traits of 30 eggs were evaluated (initial control group). The remaining 240 eggs were divided into two equal groups: control (eggs that were not subjected to any treatment) and experimental (eggs that were coated with a $5 \%$ aqueous solution of glycerol). The eggs were placed on transport trays and stored at $14{ }^{\circ} \mathrm{C}$ and $70 \%$ humidity. Quality evaluations were carried out after 14 and 28 days of storage. The depth of the air cell, mass and specific gravity of the egg, the shell characteristics (water vapour conductance, strength, mass, thickness, and density), and the content traits ( $\mathrm{pH}$ of the albumen and yolk, Haugh units, and colour and weight of the yolk) were evaluated. The results obtained suggest that the use of glycerine may contribute to slowing adverse changes in egg quality during storage by limiting $\mathrm{CO}_{2}$ removal from the egg content, which allows the egg to maintain albumen structure. Due to the fact that glycerine is a safe, cheap, and easy-to-apply substance, its large-scale use in poultry raw material storage seems to be a very real possibility.
\end{abstract}

\section{Introduction}

From the moment they are laid there are a number of changes in eggs that reduce their quality. Many factors influence the rate of these changes, ranging from genetics (Krawczyk, 2009; Batkowska and Brodacki, 2017) through to environmental variables, such as the rearing system (Batkowska et al., 2014; Batkowska et al., 2016), feed additives (Brodacki et al., 2018), or storage conditions (Akyurek and Okur, 2009).

The most important, yet simultaneously the most basic, change occurring in eggs during storage is the loss of mass caused by water evaporation (Samli et al., 2005; Calik, 2013). Loss of water is also related to the air cell depth, which increases with the length of storage time (Batkowska and Brodacki, 2014). Furthermore, quality changes regard- ing storage relate to the egg content. As a result of carbonic acid dissociation, carbon dioxide is released from the egg and alkalization of the environment occurs; this subsequently causes the $\mathrm{pH}$ of the albumen to increase (Monira et al., 2003; Mohiti-Asli et al., 2008). The change in albumen alkalinity is also influenced by the distribution of electrostatic bonds within the ovomucin-lysozyme complex, which causes significant rarefaction (Lucisano et al., 1996). In addition, a significant influence of the albumen reaction on egg functional features has been demonstrated (e.g. an impact on the quantity and stability of the foam obtained) (Mikova and Bovskova, 2009). A basic change seen in egg yolk is an increase in size and a decrease of the index value. Yolk enlargement is a process caused by the movement of water in- 


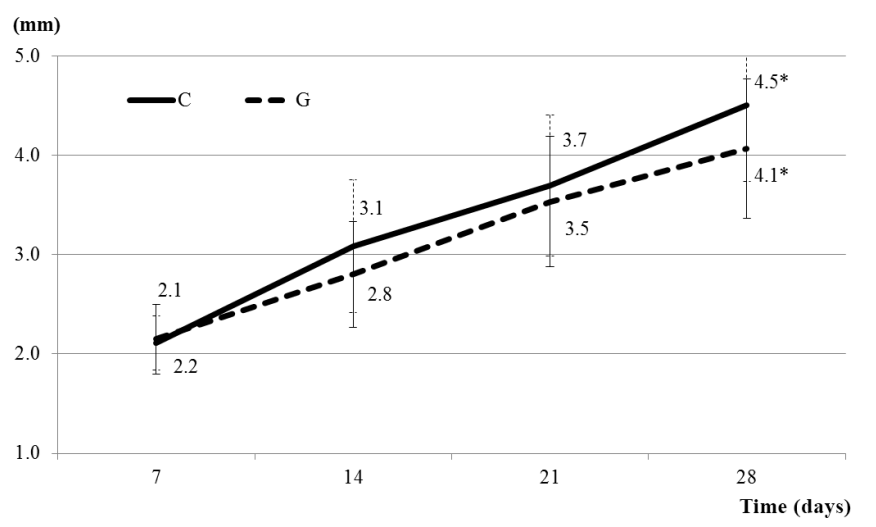

Figure 1. The air cell depth of eggs in the control and experimental groups. The ${ }^{*}$ symbol means that values differ significantly at the $p \leq 0.05$ level. $\mathrm{C}$ represents the control group; $\mathrm{G}$ represents the experimental group, treated with a $5 \%$ solution of glycerol.

side the egg, more specifically its inward diffusion through the vitelline membrane (from albumen to yolk) (Menezes et al., 2012). As the volume of the yolk increases, the strength of the vitelline membrane decreases (Jones, 2007; Kralik et al., 2014).

There are many methods to protect eggs from the diffusion process. Reduced temperature or storage in a protective atmosphere are commonly used, with the best results for inhibiting adverse changes in eggs during storage having been recorded for refrigeration temperatures ranging from 4 to $6^{\circ} \mathrm{C}$ (Scott and Silversides, 2000; Akyurek and Okur, 2009). Unfortunately, due to EU legislation, refrigerated storage is reserved exclusively for final consumers (Commission Regulation EC No. 589/2008, 2008).

The need to keep the highest level of technological traits of chicken eggs during storage, and the fact that it is not always possible to use refrigeration technology, has forced the industry to search for new solutions in this field. For this reason, substances sealing eggshell pores are used to inhibit evaporation. Previous research has proven the effectiveness of using silicone oils (Edwin et al., 2013), isolated soy and whey proteins, wax (Biladeau and Keener, 2009), gelatine (Al-Hajo et al., 2012), and vegetable oils (Ryu et al., 2011). Soya oil and mineral oil emulsions with chitosan have also been assessed as coatings (Torrico et al., 2011; Wardy et al., 2011).

It seems that glycerol should have similar coating properties to previously used coating substances. Colloquially called glycerine (propane-1,2,3-triol), glycerol is non-toxic to humans and the environment. Physically, it is a clear, colourless, odourless, and hygroscopic liquid of sweet taste (Tan et al., 2013). It is obtained from the processes involved with biofuel production from vegetable oils. Biodiesel has been produced in the European Union on an industrial scale since 1992, and currently there are around 250 plants with a production capacity of around 23 million tonnes. Glycerol is a by-product of biodiesel obtained from biomass and accounts for $10 \%$ of biofuel production (Rodrigues et al., 2017). There are many ways to dispose of glycerine, although its utilization is still insufficient. It is used on a large scale in the pharmaceutical and cosmetic industries, by the paints and dyes industry as a raw material for the synthesis of many chemical compounds (e.g. nitroglycerin, polymers), and in biosurfactants (Taherzadeh et al., 2002; Lim et al., 2018). With an increase in demand for fuels obtained from biomass the amount of glycerine waste is increasing. Therefore, there is a need to look for new directions regarding novel applications for this substance. Due to its non-toxicity, stability under storage conditions, and its ability to form a film preventing drying out, glycerine may be used to coat eggshells to reduce adverse changes in their quality during storage.

The aim of this study was to assess the possibility of moderating quality changes in table eggs during their storage by coating shells with a glycerol solution.

\section{Material and methods}

The materials utilized in this research were 270 table eggs collected on the same day. The eggs were purchased from a farm with a flock of commercial laying hens kept in a caged system (furnished cages). The birds were kept in accordance with the currently applicable legal acts (Council Directive 1999/74/EC, 1999) for maintaining proper zoohygienic and welfare conditions. The birds were fed with a balanced feed mixture adapted in terms of composition to the birds' age.

All the eggs were numbered individually. At the beginning of the experiment (day 0 ) quality characteristics of 30 eggs that constituted an initial control group were evaluated. The remaining 240 eggs were then divided into two equal groups (120 eggs in each). The experimental set-up is presented in Table 1. Eggs from the control group (C) were not subjected to any treatment. The eggs from the experimental group $(\mathrm{G})$ were placed on plastic trays and then coated with $5 \%$ aqueous glycerol solution and left for 2 min to drain the excess liquid. All eggs were subsequently placed on transport trays (30 eggs on each) with the pointy ends facing upwards, before being stored at $14{ }^{\circ} \mathrm{C}$ and $70 \%$ humidity (conditions typical for egg storage facilities).

Eggs were individually subjected to quality evaluation. At weekly intervals they were weighted and the depth of the air cell was measured. At 14-day intervals the eggs were evaluated in terms of the following characteristics: whole egg (mass and proportions of morphological elements), shell (colour, mass, thickness, and strength), albumen (height and $\mathrm{pH}$ ), and yolk (colour, index, mass, and pH). An EQM analytical set (Egg Quality Measurement, TSS $^{\circledR}$ ) and an Instron Mini 55 device were used for tests. 

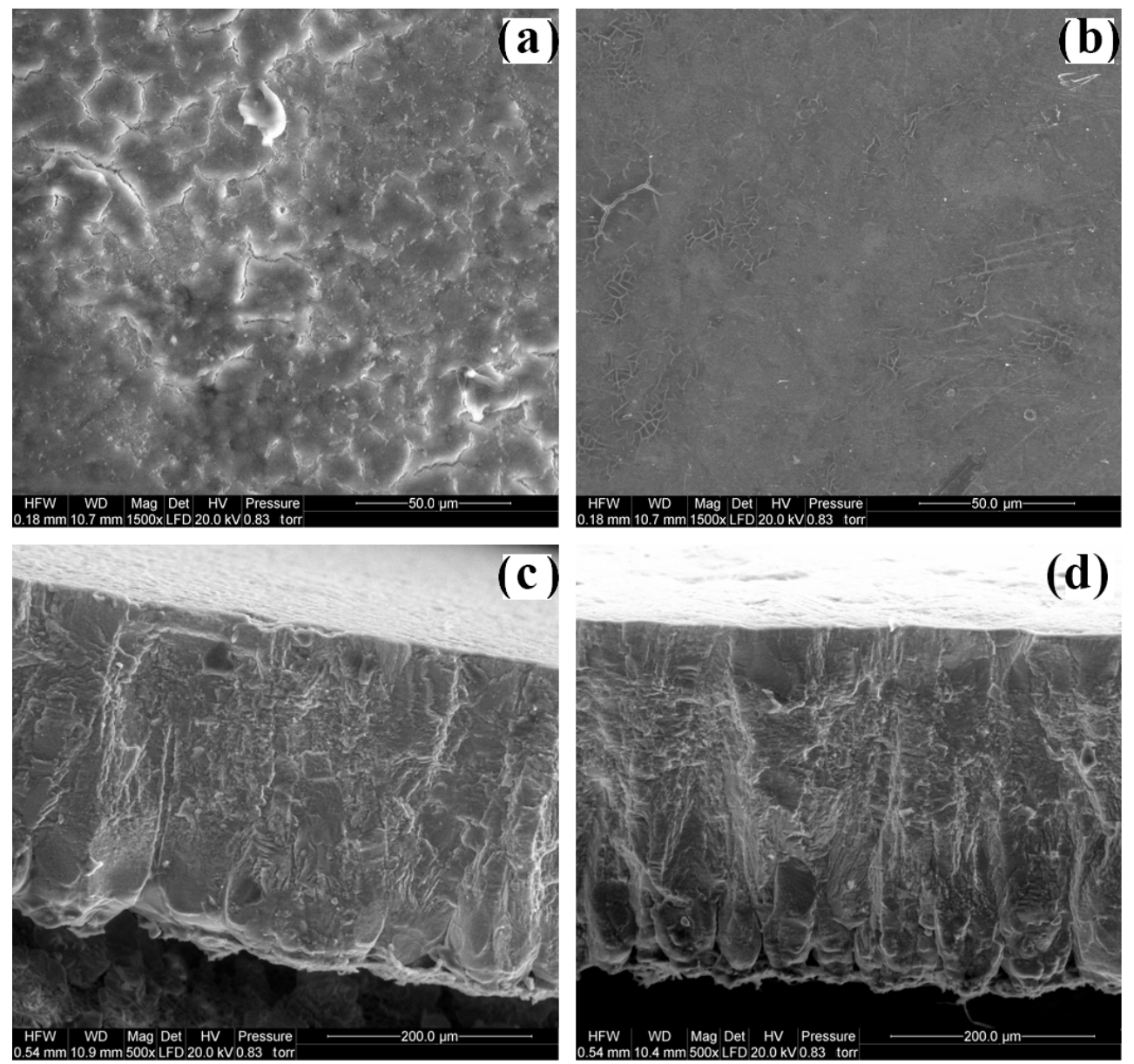

Figure 2. Scanning electron microscopy (SEM) images of the surface and a cross section of egg shells in the control group (a, c) and the experimental group $(\mathbf{b}, \mathbf{d})$, respectively.

Table 1. Experimental set-up (number of eggs).

\begin{tabular}{lcc}
\hline \multirow{2}{*}{ Time (days) } & \multicolumn{2}{c}{ Group } \\
\cline { 2 - 3 } & $\mathrm{C}$ & $\mathrm{G}$ \\
\hline 0 & 30 & \\
14 & 60 & 60 \\
28 & 60 & 60 \\
\hline Total & 150 & 120 \\
\hline
\end{tabular}

C represents the control group. $\mathrm{G}$ represents the experimental group, treated with a $5 \%$ solution of glycerol.

On the basis of the data obtained additional quality parameters were mathematically calculated, such as the specific mass of eggs, the density and the water vapour conductance of the shell (Ar et al., 1974), and the Haugh units (Williams, 1992). Additionally, after destructive evaluation, photos of egg shell surfaces and cross sections were taken us- ing a scanning electron microscope FEI QUANTA 200 SEM (Hillsboro, OR) operated at $25 \mathrm{kV}$.

The data collected during the experiment were statistically analysed using the SPSS 20.0PL statistical package (IBM Corp., 2011). The normality of the data distribution was assessed using a Kolmogorov-Smirnov test; a two-way ANOVA was then carried out. The statistical model includes two factors: the storage time and the use of glycerol, as well as the interaction between them.

\section{Results}

Table 2 presents the differentiation of whole egg characteristics depending on the storage time and the experimental factor used. A decrease in mass was observed for both the control and the experimental eggs, in relation to the storage time. An analogous relationship was found for the specific mass regardless of group. The results showed that the weight loss in eggs from the $\mathrm{C}$ group was larger than the values obtained for eggs from the $\mathrm{G}$ group. From the 15th to the 28th day of stor- 
Table 2. Traits of the whole egg in the control and experimental groups.

\begin{tabular}{|c|c|c|c|c|c|c|c|c|}
\hline \multirow[t]{2}{*}{ Trait } & \multirow[t]{2}{*}{ Time (days) } & \multicolumn{2}{|c|}{ Group } & \multirow[t]{2}{*}{ Total } & \multirow[t]{2}{*}{ SEM } & \multicolumn{3}{|c|}{ Significance of factors } \\
\hline & & $\mathrm{C}$ & G & & & Time & G & Time $\times \mathrm{G}$ \\
\hline \multirow[t]{4}{*}{ Egg weight (g) } & 0 & 60.59 & 61.22 & 60.59 & 0.969 & * & $*$ & * \\
\hline & 14 & 58.22 & 59.20 & 58.84 & 0.589 & & & \\
\hline & 28 & 57.13 & 58.69 & 58.11 & 0.606 & & & \\
\hline & Total & 58.65 & 58.95 & 58.81 & 0.392 & & & \\
\hline \multirow[t]{3}{*}{ Egg weight loss (\%) } & $0-14$ & 3.90 & 3.30 & 3.53 & 0.102 & $*$ & $*$ & $*$ \\
\hline & $15-28$ & 1.89 & 0.90 & 1.28 & 0.132 & & & \\
\hline & $0-28$ & 5.71 & 4.15 & 4.74 & 0.183 & & & \\
\hline \multirow[t]{3}{*}{ Water vapour conductance $\left(\mathrm{mg} \mathrm{H}_{2} \mathrm{O}_{\text {day }}{ }^{-1}\right.$ ) } & $0-14$ & 1.926 & 1.643 & 1.749 & 0.052 & * & * & * \\
\hline & $15-28$ & 0.892 & 0.416 & 0.594 & 0.059 & & & \\
\hline & $0-28$ & 1.409 & 1.030 & 1.172 & 0.044 & & & \\
\hline \multirow[t]{4}{*}{ Specific gravity $\left(\mathrm{g} \mathrm{cm}^{-3}\right)$} & 0 & 1.094 & & 1.094 & 0.001 & * & $*$ & * \\
\hline & 14 & 1.065 & 1.067 & 1.066 & 0.001 & & & \\
\hline & 28 & 1.053 & 1.058 & 1.056 & 0.002 & & & \\
\hline & Total & 1.075 & 1.062 & 1.069 & 0.017 & & & \\
\hline
\end{tabular}

The ${ }^{*}$ symbol means that values differ significantly at the $p \leq 0.05$ level. C represents the control group. G represents the experimental group, treated with a $5 \%$ solution of glycerol.

Table 3. Traits of egg yolk in the control and experimental groups.

\begin{tabular}{|c|c|c|c|c|c|c|c|c|}
\hline \multirow[t]{2}{*}{ Trait } & \multirow[t]{2}{*}{ Time (days) } & \multicolumn{2}{|c|}{ Group } & \multirow[t]{2}{*}{ Total } & \multirow[t]{2}{*}{ SEM } & \multicolumn{3}{|c|}{ Significance of factors } \\
\hline & & $\mathrm{C}$ & $\mathrm{G}$ & & & Time & G & Time $\times \mathrm{G}$ \\
\hline \multirow[t]{4}{*}{ Weight (g) } & 0 & 15.22 & & 15.22 & 0.202 & $*$ & - & - \\
\hline & 14 & 16.26 & 16.47 & 16.39 & 0.390 & & & \\
\hline & 28 & 15.77 & 15.58 & 15.86 & 0.169 & & & \\
\hline & Total & 15.65 & 16.19 & 15.91 & 0.171 & & & \\
\hline \multirow[t]{4}{*}{ Colour (pts) } & 0 & 13.53 & & 13.53 & 0.164 & $*$ & - & - \\
\hline & 14 & 12.50 & 12.70 & 12.60 & 0.157 & & & \\
\hline & 28 & 12.44 & 12.56 & 12.52 & 0.133 & & & \\
\hline & Total & 12.97 & 12.60 & 12.79 & 0.094 & & & \\
\hline \multirow[t]{4}{*}{ Index $(\%)$} & 0 & 44.47 & & 44.47 & 0.579 & $*$ & $*$ & $*$ \\
\hline & 14 & 37.70 & 40.22 & 39.27 & 0.559 & & & \\
\hline & 28 & 34.13 & 38.27 & 36.75 & 0.522 & & & \\
\hline & Total & 40.07 & 39.26 & 39.70 & 0.434 & & & \\
\hline \multirow[t]{4}{*}{$\mathrm{pH}$} & 0 & 6.29 & & 6.29 & 0.013 & $*$ & - & - \\
\hline & 14 & 6.39 & 6.34 & 6.36 & 0.018 & & & \\
\hline & 28 & 6.54 & 6.38 & 6.46 & 0.047 & & & \\
\hline & Total & 6.40 & 6.36 & 6.39 & 0.021 & & & \\
\hline \multirow[t]{4}{*}{ Proportion of egg weight (\%) } & 0 & 24.99 & & 24.99 & 0.291 & $*$ & - & - \\
\hline & 14 & 26.60 & 26.68 & 26.65 & 0.271 & & & \\
\hline & 28 & 26.62 & 27.10 & 26.92 & 0.300 & & & \\
\hline & Total & 25.87 & 26.89 & 26.36 & 0.181 & & & \\
\hline
\end{tabular}

The * symbol means that values differ significantly at the $p \leq 0.05$ level. C represents the control group. G represents the experimental group, treated with a $5 \%$ solution of glycerol. 
Table 4. Traits of egg albumen in the control and experimental groups.

\begin{tabular}{|c|c|c|c|c|c|c|c|c|}
\hline \multirow[t]{2}{*}{ Trait } & \multirow[t]{2}{*}{ Time (days) } & \multicolumn{2}{|c|}{ Group } & \multirow[t]{2}{*}{ Total } & \multirow[t]{2}{*}{ SEM } & \multicolumn{3}{|c|}{ Significance of factors } \\
\hline & & $\mathrm{C}$ & $\mathrm{G}$ & & & Time & $\mathrm{G}$ & Time $\times \mathrm{G}$ \\
\hline \multirow[t]{4}{*}{ Weight (g) } & 0 & 37.46 & & 37.46 & 0.673 & $*$ & - & - \\
\hline & 14 & 37.19 & 35.10 & 35.89 & 0.660 & & & \\
\hline & 28 & 33.52 & 35.52 & 34.77 & 0.797 & & & \\
\hline & Total & 36.31 & 35.31 & 35.83 & 0.432 & & & \\
\hline \multirow[t]{4}{*}{ Height (mm) } & 0 & 8.33 & & 8.33 & 0.243 & $*$ & $*$ & $*$ \\
\hline & 14 & 5.02 & 6.67 & 6.02 & 0.212 & & & \\
\hline & 28 & 4.47 & 6.61 & 5.84 & 0.231 & & & \\
\hline & Total & 6.37 & 6.64 & 6.50 & 0.160 & & & \\
\hline \multirow[t]{4}{*}{ Haugh units } & 0 & 90.50 & & 90.50 & 1.204 & $*$ & $*$ & $*$ \\
\hline & 14 & 68.22 & 80.84 & 75.59 & 1.539 & & & \\
\hline & 28 & 63.68 & 80.01 & 74.40 & 1.594 & & & \\
\hline & Total & 77.11 & 80.43 & 78.69 & 1.065 & & & \\
\hline \multirow[t]{4}{*}{$\mathrm{pH}$} & 0 & 8.25 & & 8.25 & 0.039 & $*$ & * & $*$ \\
\hline & 14 & 9.10 & 8.56 & 8.81 & 0.052 & & & \\
\hline & 28 & 9.11 & 8.68 & 8.88 & 0.040 & & & \\
\hline & Total & 8.80 & 8.62 & 8.72 & 0.037 & & & \\
\hline \multirow[t]{4}{*}{ Proportion of egg weight (\%) } & 0 & 61.54 & & 61.54 & 0.317 & $*$ & - & - \\
\hline & 14 & 60.21 & 60.01 & 60.08 & 0.296 & & & \\
\hline & 28 & 60.10 & 59.30 & 59.60 & 0.349 & & & \\
\hline & Total & 60.78 & 59.65 & 60.25 & 0.200 & & & \\
\hline
\end{tabular}

The * symbol means that values differ significantly at the $p \leq 0.05$ level. C represents the control group. G represents the experimental group, treated with a $5 \%$ solution of glycerol.

age, this parameter amounted to $1.89 \%$ for the control group and $0.90 \%$ for the experimental group. The percentage loss of mass and the calculated water vapour conductance of the shell also showed significant differences between the analysed groups. Eggs coated with glycerine lost about $1.5 \%$ less water than eggs from the control group. These differences were most evident from the 15th day through to the end of research. For all characteristics of the whole egg, a significant effect of both of the abovementioned main factors as well as an interaction between them was demonstrated.

The dependence of the air cell depth on the storage time is shown in Fig. 1. It was observed that the magnitude of this indicator increased over time, independently of the tested group, and after 14 days of storage there were differences between the eggs coated with glycerine and the control group. The air cell in the experimental group was visibly deeper in comparison to the control group. After 28 days of storage the air chamber in eggs from the $G$ group was significantly shallower than in the $\mathrm{C}$ group.

Egg yolk traits of groups included in the experiment are illustrated in Table 3. The yolk mass increased with storage time regardless of the group. At the same time, no significant differences were found between the C and G groups. Dur- ing storage, the yolk colour lost intensity irrespective of the factor used, although yolks from eggs coated with glycerol lost colour intensity at a slightly slower rate than the control group. Similar relationships are seen regarding the yolk reaction. Irrespective of the group, $\mathrm{pH}$ increased with storage time; however, the alkalization process was slower in eggs from the experimental group. Furthermore, the yolk index decreased with storage time in all eggs. It was observed that eggs that were coated with glycerol solution showed significantly higher yolk index values, both after 14 days and after 28 days of storage. This indicates an increased ability to maintain the proper shape of this element for longer in eggs of this group. This index was also influenced considerably by the interaction of both analysed factors. Moreover, it was observed that the storage time also affected the change of the yolk proportion of the egg weight. The values of this feature increased with time regardless of group. In the experimental group a slightly lower percentage of yolk was observed after 28 days than in $\mathrm{C}$ group.

During the evaluation of albumen qualitative characteristics (Table 4), it was found that the mass of the albumen decreased over time regardless of the experimental factor used. Analysing the dense albumen height and related Haugh units 
Table 5. Traits of egg shell in the control and experimental groups.

\begin{tabular}{|c|c|c|c|c|c|c|c|c|}
\hline \multirow[t]{2}{*}{ Trait } & \multirow[t]{2}{*}{ Time (days) } & \multicolumn{2}{|c|}{ Group } & \multirow[t]{2}{*}{ Total } & \multirow[t]{2}{*}{ SEM } & \multicolumn{3}{|c|}{ Significance of factors } \\
\hline & & $\mathrm{C}$ & $\mathrm{G}$ & & & Time & G & Time $\times \mathrm{G}$ \\
\hline \multirow[t]{4}{*}{ Colour $(\%)$} & 0 & 24.20 & & 24.20 & 0.663 & $*$ & $*$ & $*$ \\
\hline & 14 & 24.00 & 26.13 & 29.67 & 0.909 & & & \\
\hline & 28 & 27.22 & 28.07 & 26.54 & 0.676 & & & \\
\hline & Total & 27.24 & 27.10 & 27.17 & 0.495 & & & \\
\hline \multirow[t]{4}{*}{ Strength (N) } & 0 & 57.53 & & 57.53 & 2.633 & * & - & - \\
\hline & 14 & 53.13 & 50.32 & 50.80 & 2.255 & & & \\
\hline & 28 & 60.39 & 60.02 & 60.15 & 1.495 & & & \\
\hline & Total & 57.00 & 54.67 & 55.89 & 1.261 & & & \\
\hline \multirow[t]{4}{*}{ Weight (g) } & 0 & 8.20 & & 8.20 & 0.147 & - & - & - \\
\hline & 14 & 7.46 & 7.91 & 7.91 & 0.097 & & & \\
\hline & 28 & 7.79 & 8.03 & 7.94 & 0.104 & & & \\
\hline & Total & 8.01 & 7.97 & 7.99 & 0.065 & & & \\
\hline \multirow[t]{4}{*}{ Thickness (mm) } & 0 & 0.334 & & 0.334 & 0.008 & - & - & - \\
\hline & 14 & 0.337 & 0.343 & 0.340 & 0.004 & & & \\
\hline & 28 & 0.320 & 0.310 & 0.314 & 0.005 & & & \\
\hline & Total & 0.331 & 0.326 & 0.329 & 0.003 & & & \\
\hline \multirow[t]{4}{*}{ Density $\left(\mathrm{g} \mathrm{cm}^{-3}\right)$} & 0 & 3.40 & & 3.40 & 0.094 & - & - & - \\
\hline & 14 & 3.29 & 3.22 & 3.25 & 0.053 & & & \\
\hline & 28 & 3.42 & 3.64 & 3.56 & 0.066 & & & \\
\hline & Total & 3.37 & 3.43 & 3.40 & 0.041 & & & \\
\hline \multirow[t]{4}{*}{ Proportion of egg weight $(\%)$} & 0 & 13.47 & & 13.47 & 0.142 & - & - & - \\
\hline & 14 & 13.20 & 13.31 & 13.27 & 0.136 & & & \\
\hline & 28 & 13.28 & 13.60 & 13.48 & 0.154 & & & \\
\hline & Total & 13.34 & 13.46 & 13.40 & 0.085 & & & \\
\hline
\end{tabular}

The * symbol means that values differ significantly at the $p \leq 0.05$ level. C represents the control group. G represents the experimental group, treated with a $5 \%$ solution of glycerol.

it was also found that storage time reduced both values, but the use of glycerine solution reduced the intensity of these changes. Statistically significant differences between groups indicate the effectiveness of the glycerine solution in slowing the dilution of the dense protein fraction. In terms of the protein reaction, an increase in alkalinity was observed depending on storage time. In the experimental group, a significantly faster increase in $\mathrm{pH}$ was observed compared to the control group; this was confirmed by statistical analysis. It is noteworthy that, regardless of analysis date, values in the experimental group were similar to values found in fresh eggs. The height of the structural albumen, the associated Haugh units, and the albumen reaction were influenced by both experimental factors and the interaction between them. Furthermore, the storage time decreased the albumen proportion in eggs. Despite the lack of a statistical confirmation of the differences, after 28 days of storage, eggs from the
C group were found to have an albumen content that was slightly lower than eggs in the $\mathrm{G}$ group.

The quality of the shell may be an important aspect impacting egg storage. The analysed features of the egg shell are presented in Table 5. Based on storage time, changes in shell colour were observed: significantly more light was reflected by the shells of older and glycerine-coated eggs. There was also an increase in shell strength over time. Other traits such as mass, thickness, density, or proportion of the egg weight, despite slight differentiation, were not influenced by either individual experimental factors or their interaction.

In Fig. 2 the shell surface and a cross section of egg shell from both the control and experimental groups are shown. It can be observed that the shell coated with glycerine has a very smooth surface (Fig. 2b and d) compared to the control group (Fig. 2a and c). It is also possible to see sealed-up pores in the shell cross section for the G group (Fig. 2d), which could reflect results obtained for other quality traits. 


\section{Discussion}

Regardless of the experimental treatment used during storage, a loss of egg mass was observed. It is directly related to the transport of water and carbon dioxide through the pores in the shell, from the egg content to environment and vice versa (with twice smaller intensity) (Campo et al., 2000). Mass losses for the control group agree with those found by Akyurek and Okur (2009) for a similar storage period. The use of protective coatings has a positive effect on inhibiting egg mass loss during storage, which is confirmed by both the results obtained in the experimental group in this study and observations made by other authors (Edwin et al., 2013; Ryu et al., 2011; Wardy et al., 2011; Eke et al., 2013). Glycerine was found to reduce the egg mass loss more than mineral oil and chitosan emulsion (Wardy et al., 2011); however, the results obtained in this study had lower values compared to vegetable oils (Ryu et al., 2011) for the same storage time.

Research by Akyurek and Okur (2009) indicated an increase in air cell depth during egg storage, and they obtained results in the range of 7.04-7.72 $\mathrm{mm}$; this is much higher than the values found in our study, which ranged between 3.5 and $3.7 \mathrm{~mm}$ for the same storage time. However, the eggs in the cited study were stored at a higher temperature $\left(20^{\circ} \mathrm{C}\right)$; furthermore, the results may also have been influenced by hen age.

The basic parameter for assessing albumen quality is Haugh units, which are calculated based on the albumen height. As a function of storage time, the height of the dense fraction of the albumen decreases, which means that the Haugh units also decrease. The shell coating affects the release of $\mathrm{CO}_{2}$ and the alkalization of the environment and slows down negative changes in the albumen quality. Similar results were obtained for chitosan (Torrico et al., 2011), vegetable oils (Ryu et al., 2011), and wax (Biladeau and Keener, 2009). However, among the coatings listed (for similar storage periods), the best results were found for eggs coated with glycerine solution, which may indicate the effectiveness of its use.

The movement of water in an egg's content affects changes in the proportions of morphological elements with respect to the egg weight. The diffusion of water from the albumen to the yolk (Menezes et al., 2012) increases the yolk mass, while reducing the value of its index. The results of the yolk index in this study are comparable to those obtained for soybean oil and chitosan-soybean oil emulsions (Wardy et al., 2011) and vegetable oils (Ryu et al., 2011).

Research results regarding the albumen $\mathrm{pH}$ range indicate the effectiveness of glycerine for inhibiting carbon dioxide release from the egg content. Thus, limiting carbon dioxide diffusion with substances that seal the shell can have a positive effect on the $\mathrm{pH}$ of the egg content and, as a result, on its technological properties. Similar observations were made by Ryu et al. (2011) and Biladeau and Keener (2009), who used other coating substances. The yolk reaction also changed more slowly in the experimental group compared to the control group, which indicates that shell coating inhibits negative qualitative changes. However, the results obtained show lower efficacy compared to wax regarding this parameter (Biladeau and Keener, 2009).

\section{Conclusions}

Studies have shown that coating egg shells with glycerine solution inhibited some of the negative changes that occur during storage. It seems that the use of glycerine reduced gas exchange between the egg content and the environment, which limited the removal of carbon dioxide from the egg content. Therefore, the albumen structure and the egg's technological quality traits were preserved. Maintenance of the correct ratio between the diameter and the yolk height limited the weakening of the vitelline membrane and protected the egg content from mixing.

The results obtained suggest that the use of a glycerine solution may contribute to reducing adverse changes in egg quality during storage. As glycerine is completely safe, cheap and relatively easy in application, the possibility of its largescale use in poultry raw material storage seems to be feasible; however, it is necessary to extend current research with rheological, sensory, and microbiological evaluations of eggs in storage.

Data availability. The original data are available upon request from the corresponding author.

Author contributions. All authors contributed to the work described in the paper. KD designed the experiment. KD, PC, KV and JB performed the research. JB analyzed the data. KD, AA and JB wrote the paper. All authors read and approved the final paper.

Competing interests. The authors declare that they have no conflict of interest.

Acknowledgements. Authors would like to thank Krzyszof Damaziak, from Warsaw University of Life Sciences for his support during the preparation of the SEM images.

Edited by: Manfred Mielenz

Reviewed by: two anonymous referees

\section{References}

Akyurek, H. and Okur, A. A.: Effect of storage time, temperature and hen age on egg quality in free-range layer hens, J. Anim. Vet. Adv., 8, 1953-1958, 2009. 
Al-Hajo, N. N., Zangana, B. S., Al-Janabi, L. A., and Al-Khalani, M. H. F.: Effect of coating materials (gelatin) and storage time on internal quality of chicken and quail eggs under refrigerated storage, Egypt. Poult. Sci. J., 32, 107-115, 2012.

Ar, A., Paganelli, C. V., Reeves, R. B., Greene, D. G., and Rahn, H.: The avian egg: water vapor conductance, shell thickness, and functional pore area, Condor, 76, 153-158, 1974.

Batkowska, J. and Brodacki, A.: Selected quality traits of eggs and the productivity of newly created laying hen hybrids dedicated to an extensive rearing system, Arch. Anim. Breed., 60, 87-93, 2017.

Batkowska, J., Brodacki, A., and Knaga, S.: Quality of laying hen eggs during storage depending on egg weight and type of cage system (conventional vs. furnished cages), Ann. Anim. Sci., 14, 707-719, 2014.

Batkowska, J., Brodacki, A., and Gryzińska, M.: Effects of laying hen husbandry system and storage on egg quality, Europ. Poult. Sci., 80, https://doi.org/10.1399/eps.2016.158, 2016.

Biladeau, A. M. and Keener, K. M.: The effects of edible coatings on chicken egg quality under refrigerated storage, Poult. Sci., 88, 1266-1274, 2009.

Brodacki, A., Batkowska, J., Stępniowska, A., Blicharska, E., and Drabik, K.: Quality and mineral composition of eggs from hens supplemented with copper-lysine chelate, Arch. Anim. Breed., 61, 109-113, 2018.

Calik, J.: Changes in quality traits of eggs from yellowleg partridge ( $\dot{\mathrm{z}}-33)$ laying hens depending on storage conditions of eggs, Zywn.-Nauk. Technol. Ja., 20, 73-79, 2013 (in Polish with abstract in English).

Campo, J. L., Garcia, G. M., Muńdoz, I., and Alonso, M.: Effects of breed, hen age, and storage on the indirect prediction of the albumen quality, Arch. Geflügelkd., 64, 109-114, 2000.

Commission Regulation (EC) No. 589/2008 of 23 June 2008 laying down detailed rules for implementing Council Regulation (EC) No. 1234/2007 as regards marketing standards for eggs, Official Journal L 163, 24 June 2008, 6-23, 2008.

Council Directive 1999/74/EC of 19 July 1999 laying down minimum standards for the protection of laying hens, Official Journal L 203, 24 June 2008, 53-57, 1999.

Edwin, S. C., Babu, M., Moorthy, M., Amutha, R., Ranjendran, K., and Anandhi, M.: Quality preservation of commercial chicken eggs in different non-refrigeration methods, Indian Vet. J., 90, 87-89, 2013.

Eke, M. O., Olaitan, N. I., and Ochefu, J. H.: Effect of storage conditions on the quality attributes of shell (table) eggs, N.I.F.O.J., 31, 18-24, 2013.

IBM Corp.: SPSS Statistics for Windows, Version 20.0, Armonk, New York, United States, IBM Corporation, 2011.

Jones, D. R.: Egg functionality and quality during long-term storage, Int. J. Poult. Sci., 6, 157-162, 2007.

Kralik, Z., Kralik, G., Grcević, M., and Galović, A.: Effect of storage period on the quality of table eggs, Acta Agraria Kaposváriensis, 18, 200-206, 2014.

Krawczyk, J.: Effect of layer age and egg production level on changes in quality traits of eggs from hens of conservation breeds and commercial hybrids, Ann. Anim. Sci., 9, 185-193, 2009.
Lim, C., Lin, A. L., and Zhao, H.: Metabolic strategies for microbial glycerol overproduction, J. Chem. Technol. Biot., 93, 624-628, https://doi.org/10.1002/jctb.5465, 2018.

Lucisano, M., Hidalgo, A., Comelli, E. M., and Rossi, M.: Evolution of chemical and physical albumen characteristics during the storage of shell eggs, J. Agr. Food Chem., 44, 1235-1240, 1996.

Menezes, P. C. D., Lima, E. R. D., Medeiros, J. P. D., Oliveira W. N. K. D., and Evêncio-Neto, J.: Egg quality of laying hens in different conditions of storage, ages and housing densities, Rev. Bras. Zootecn., 41, 2064-2069, 2012.

Mikova, K. and Bovskova, H.: Optimization of egg white foam forming, Proceedings of the 13th Eur. Symp. on the Quality of Eggs and Egg Products, WPSA, Turku, Finland, 21-25, 1-10, 2009.

Mohiti-Asli, M., Shariatmadari, F., Lotfollahian, H., and Mazuji, M. T.: Effects of supplementing layer hen diets with selenium and vitamin $\mathrm{E}$ on egg quality, lipid oxidation and fatty acid composition during storage, Can. J. Anim. Sci, 88, 475-483, 2008.

Monira, K., Salahuddin, M., and Miah, G.: Effect of breed and holding period on egg quality characteristics of chicken, Int. J. Poult. Sci., 4, 261-263, 2003.

Rodrigues, A., Bordado, J. C., and Santos, R. G. D.: Upgrading the glycerol from biodiesel production as a source of energy carriers and chemicals - a technological review for three chemical pathways, Energies, 10, 1817, https://doi.org/10.3390/en10111817, 2017.

Ryu, K. N., No, H. K., and Prinyawiwatkul, W.: Internal quality and shelf life of eggs coated with oils from different sources, J. Food Sci., 76, 325-329, 2011.

Samli, H. E., Agma, A., and Senkoylu, N.: Effects of storage time and temperature on egg quality in old laying hens, J. Appl. Poultry Res., 14, 548-553, 2005.

Scott. T. A. and Silversides, F. G.: The effect of storage and strain of hen on egg quality, Poult. Sci., 79, 1725-1729, 2000.

Taherzadeh, M. J., Adler, L., And Lidén, G.: Strategies for enhancing fermentative production of glycerol - a review, Enzyme Microb. Tech., 31, 53-66, 2002.

Tan, H. W., Aziz, A. A., and Aroua, M. K.: Glycerol production and its applications as a raw material: A review, Renew. Sust. Energ. Rev., 27, 118-127, 2013.

Torrico, D. D., No, H. K., Prinyawiwatkul, W., Janes, M., Corredor, J. A., and Osorio, L. F.: Mineral oil-chitosan emulsion coatings affect quality and shelf-life of coated eggs during refrigerated and room temperature storage, J. Food Sci., 76, 5262-5268, 2011.

Wardy, W., Torrico, D. D., Jirangrat, W., No, H. K., Saalia, F. K., and Prinyawiwatkul, W.: Chitosan-soybean oil emulsion coating affects physico-functional and sensory quality of eggs during storage, LWT-Food Sci. Technol., 44, 2349-2355, 2011.

Williams, K. C.: Some factors affecting albumen quality with particular reference to Haugh unit score, Worlds Poultry Sci. J., 48, 5-16, 1992. 